\title{
Journal of Black Studies
}

http://jbs.sagepub.com

\section{Continually Neglected: Situating Natural Disasters in the African American Experience \\ Jason David Rivera and DeMond Shondell Miller} Journal of Black Studies 2007; 37; 502

DOI: $10.1177 / 0021934706296190$

The online version of this article can be found at: http://jbs.sagepub.com/cgi/content/abstract/37/4/502

\author{
Published by: \\ (5) SAGE Publications \\ http://www.sagepublications.com
}

Additional services and information for Journal of Black Studies can be found at:

Email Alerts: http://jbs.sagepub.com/cgi/alerts

Subscriptions: http://jbs.sagepub.com/subscriptions

Reprints: http://www.sagepub.com/journalsReprints.nav

Permissions: http://www.sagepub.com/journalsPermissions.nav 


\title{
CONTINUALLY NEGLECTED Situating Natural Disasters in the African American Experience
}

\author{
JASON DAVID RIVERA \\ DEMOND SHONDELL MILLER \\ Rowan University
}

\begin{abstract}
It is perplexing why natural disasters, as important life-altering events, are seldom viewed as a catalyst for social change in the United States in general but particularly for African Americans. This article addresses a gap in literature by proposing natural disasters as a variable to help understand the African American experience. The authors argue that the first post-Civil War migration altered the life courses for many. Subsequent to the first migration wave (the Great Migration of 1916-1930), environmental factors altered many African American lives. Natural disasters such as The Great Mississippi River Flood of 1927, The 1948 Vanport Flood, and Hurricane Katrina illustrate the federal government's indifference and neglect of responsibility, which played a role in decisions to migrate. These major natural environmental disasters, when situated in historical context as a part of the social, political, geographical, and economic landscape, are vital in the understanding of the African American experience.
\end{abstract}

Keywords: Hurricane Katrina; natural disaster; Flood of 1927; Vanport flood

\section{INTRODUCTION: “GOD'S GONNA TROUBLE THE WATER"}

The work of Rachel Carson (1962), Silent Spring, in the 1960s, ushered in the beginning of the modern environmental movement in the United States. However, until the pioneering works of Robert Bullard (1990a, 1990b, 2000) that detailed environmental injustices, environmental inequities concerning race, class, and gender were 
often overlooked as a traditional part of the environmental movement. The African American experience is rooted in a history of inequity. A great deal of literature focusing on the African American experience, as it relates to the environment, is centered on environmental justice (EJ). EJ is "an intersection of emerging social movements, technological advances in geographical information systems and spatial statistics, and a growing number of policymaker['s] interest in disproportionately affected communities" (Pastor et al., 2006, p. 1), which is more concerned with asking the question, Why do some racial, ethnic, and lower socioeconomic status communities seem to suffer the brunt of more environmental danger than other communities? EJ offers a unique way to view disaster vulnerability, public policy implications, emergency preparedness, disaster response, and recovery. However, although this perspective is keen for identifying trends, documenting evidence, and exposing many injustices, it does not view the natural disaster as a critical factor in the development of the course of the African American experience. In the three case studies presented, we argue that the natural disasters set in motion patterns of change not only to the physical landscapes but also to the demographic and cultural environments, leading to the collapse of the old South. ${ }^{1}$ Oliver-Smith (2005) contends that now, more than ever, natural disasters such as Hurricane Katrina bring with them an enormous potential to uproot large numbers of people, forcing the involuntary internal displacement of communities and giving people a status similar to that of a refugee in one's own land.

The increasing complexity of natural disasters is embedded in the interplay of geospatial, social, cultural, and economic factors in a community's environment. This interplay exacerbates the vulnerability of people and their community environments, intensifying disaster impacts when they occur (Oliver-Smith, 2005). Although

\footnotetext{
AUTHORS' NOTE: An earlier draft of this article was presented at the 32nd Annual Meeting of the Mid-South Sociological Association, October 25-28, 2006, in Lafayette, Louisiana. The authors wish to thank Tradell Adkins for his support and critical reflection in the preparation of this article. They also express gratitude to Cindy Castelli for her editorial assistance and the Interlibrary Loan Department staff in Campbell Library at Rowan University, Elaine M. Gatton, Joyce McCaughey, and Faye E. Robinson, for their assistance.
} 
devastating and life-altering tragedies, natural disasters have profound environmental implications for affected regions in the past, present, and future. Hence, by learning lessons from actions after The Great Flood of 1927, The Vanport Flood of 1948, and Hurricane Katrina, the principles of equity and fair distribution of environment risks can be incorporated into public policy.

\section{THE GREAT FLOOD OF 1927}

Within a few generations of the Emancipation Proclamation, the social and political environment of the South became inhospitable for African Americans. Hence, streams of African Americans seeking opportunities began leaving the South soon after Reconstruction. ${ }^{2}$ The period known as the Great Migration began after World War I as sharecroppers sought out industrial jobs in the more urbanized North:

In a three-year span from 1916 to 1919, in what has been called the "Great Migration," over half a million African American[s] fled the South with the prospect of seeking higher wages. Another million left in the 1920s. During the Great Depression, when African American sharecroppers were turned away from the farms, thousands of them joined relatives and friends in Chicago, Detroit, Pittsburgh, New York, and Los Angeles. (Davis, 2003)

In an attempt to escape the rigid race-based social hierarchy, poverty, lack of educational opportunities, and racial violence, many saw no other option but to migrate. Laws in the Mississippi Delta had never offered much protection for African Americans, and with the rise of the Ku Klux Klan as a homegrown terrorist organization in the 1920s, the violence only intensified, developing a culture of mob violence and lynching against African Americans for the purposes of intimidation and "keeping them in their place." It is important to note that the 1920s was characterized as a period that saw an explosion of Klan activity as thousands of African Americans were brutalized and terrorized. According to Davis (2003), the federal government attempted to stop such activities through the use of investigations and the military, but these efforts had little or no effect. So widespread were the limitations on 
African Americans that "by 1910, every state of the former Confederacy had adopted laws that segregated all aspects of life (especially schools and public places) wherein blacks and whites might socially mingle or come into contact" (Davis, 2003). Many African American migrants were pushed out of the South by a series of natural disasters, such as frequent flooding and the boll weevil scourge, which devastated cotton crops from Texas to Georgia (Davis, 2003).

For days, the rain fell in early summer of 1927 and caused the Mississippi River to swell beyond its banks, weakening the levee system around New Orleans and sending white-capped brown water into communities largely inhabited by African Americans (Slivka, 2005). This pivotal event in pre-integration times marked the first great natural disaster faced by the country. So great was this catastrophe, that the flood covered an area comparable to the size of New England. In the entire seven-state flood zone, nearly 250 people were killed and more than 700,000 were displaced; moreover, the damages incurred totaled nearly one third of the national budget (Slivka, 2005). During this massive flood, African American communities in New Orleans and other parts of the South, particularly Greenville, Mississippi, were left to fend for themselves.

In Louisiana, the weakest levees lay 30 miles up-river from New Orleans, and any weakening of the levees would flood the city from the rear, as it had during the city's prior major flood in 1849. These levees, which were so significantly relied on, offered little protection to the city, and according to one city official, the protection offered was only theoretical (Barry, 1997; Miller \& Rivera, in press; National Flood Commission, 1927). Racial overtones colored every aspect of the attempts to save its residents. Evacuation opportunities and relief supplies went to the Whites first, and then, if supplies or boats remained, the African Americans were allowed to take what was left (Miller and Rivera, in press; WGBH Educational Foundation, 2001; see also Public Broadcasting Service, 2000). African Americans were so low a priority during rescue attempts that in some instances animals were rescued before them: 
A letter from a black Republican activist read: "It is said that many relief boats have hauled whites only, have gone to imperiled districts and taken all whites out and left the Negroes; it is also said that planters in some instances hold their labor at the point of gun for fear they would get away and not return. In other instances, it is said that mules have been given preference on boats to Negroes." (Barry, 1997, p. 320; see also Miller \& Rivera, in press; Redmond, 1927, as cited in Barry, 1997)

As the rains continued to fall and break existing records, the Gulf of Mexico was also at its highest, giving the water draining from the Mississippi River no place to go. The amount of water from the river and the pressure exerted by water already in the Gulf of Mexico proved too much for the tributaries feeding into the Mississippi River in addition to the levee system used to protect New Orleans. When the city's elite concluded that a flood was eminent and it would devastate the region's economy, they crafted a plan to destroy parts of the levee in adjacent states; however, officials from surrounding states used police to protect the levees from sabotage (Miller \& Rivera, in press; WGBH Educational Foundation, 2001). In reaction, city officials devised another plan to destroy part of the levee system around New Orleans. According to Slivka (2005),

To save New Orleans, the leaders proposed a radical plan. South of the city, the population [was] mostly rural and mostly poor. The leaders appealed to the federal government to essentially sacrifice those parishes by blowing up an earthen levee and diverting the water into marshland. They promised restitution to people who lost their homes. Government officials, including Commerce Secretary Herbert Hoover, signed off.

On April 29, the levee at Caernarvon, 13 miles south of New Orleans, succumbed to 39 tons of dynamite. The river rushed through at 250,000 cubic feet per second. New Orleans was saved, but the misery of the flooded parishes had only started. The city fathers took years to make good on their promise[s], and few residents ever saw any compensation at all. (p. 26)

At the time of the levee's destruction, there were few concerns about the welfare of the African American population residing in the marshland used as drainage. 
The flood of 1927 was the first natural disaster in recorded history to have such dire consequences for African Americans. The dysfunctional realities of the South's pre-integration agricultural industry led to the social and political neglect of African Americans that set in motion their second great mass migration, mainly consisting of share croppers to the north, resulting in the final dismantling of the intuitional remnants of slavery:

Most significant for the course of America, however, the tragedy [flood of 1927] that hastened the mass migration of African Americans to northern cities and marked the beginning of the end of Southern sharecropping. "You'd say, 'I'd like to talk to you about the 1927 flood,' and you didn't need to explain anything else," says Pete Daniel, author of Deep'n As It Come: The 1927 Mississippi River Flood. "It was the most significant thing in their [African American sharecroppers] lives." (Slivka, 2005, p. 26)

Finally, according to Oliver-Smith (2005), The Great Flood of 1927 displaced approximately 330,000 African Americans who were subsequently interned in 154 relief ("concentration") camps where they were forced to work. ${ }^{3}$ Although there were many reasons for African Americans to leave the South-high unemployment, insect infestation of crops, urban job prospects, lynch mobs, more political and social freedom, and so forth-the flood and its consequences were the final motivation for thousands to migrate (see Barry, 1997; Oliver-Smith, 2005). Between 1916 and 1930, the Great Migration was underway, and by 1927, the flood turned a voluntary steady migration stream into an involuntary mass in search for basic shelter:

The aftermath of the flood was one factor in the Great Migration of African Americans to northern cities. Previously, the move from the rural South to the Northern cities had virtually stopped. As a result of displacement lasting up to six months, millions of Southern blacks moved to the big cities of the North, particularly Chicago. (Wikipedia, 2006a)

The magnitude of such an influx of people proved to be too great for the local, state, and federal initiative to handle. Failure to have a disaster plan, along with inequitable policies that favored the wealthy 
landowning class, led to reactionary tactics such as forced work camps that encouraged multitudes to leave the region and never return.

\section{PORTLAND, OREGON, AND THE VANPORT FLOOD OF 1948}

Similar to the racial discrimination and civil rights violations that occurred during the Mississippi Flood of 1927, the Vanport Flood of 1948 brought the social situation of the African American community to the forefront of regional news. Like most of the United States at the time, African Americans in the Portland, Oregon, area experienced racial segregation and discrimination from the local government and White individuals. When the flood eventually struck, the social situation for the Portland-area African American community was bleak.

When the flood occurred, Portland had been practicing a racial policy adopted in the state's 1857 constitution. The policy allowed city officials and union leaders to exclude the non-White population of Oregon from social and economic equality. Application of discriminatory policies was relatively easy in the state prior to World War II, specifically because of a low African American population (1940 Census Report, 1940; Pearson, 1996). Within the city of Portland, the local residents claimed "good" relations between its African American and White populations; however, Pearson (1996) states that this standing relationship lasted as long as "Black people stayed 'in their place" " (pp. 13-14).

In the 1940s, there was an influx of African American workers into the area because of the prospect of earning high wages in the defense industry (Pearson, 1996). The potential to make a living in the defense industry was conceivably high for African Americans at the time, especially with an Executive Order from Franklin Delano Roosevelt prohibiting discrimination in the defense industry. ${ }^{4}$ With the reassurance of the President that jobs would be available to anyone who wanted one, between 1942 and 1945, the prospect of acquiring a defense industry job brought 160,000 people to Portland, 15\% of whom were African American (Pearson, 1996; Urban League Report-The Battle Against Bigotry, circa 1948). 
Increased African American presence in the city did not occur without native White resentment. As early as 1942, there are attacks in local newspapers against defense industries in the area, mentioning that they were actively recruiting African Americans, further enticing them to move into the area (Oregonian, 1942, as cited in Pearson, 1996). Although there was concern that African Americans would take the most attractive positions from the native White population, these concerns were unfounded. Skilled or not, African American workers were forced to be unskilled workers, making 88 cents an hour as opposed to their White skilled worker counterparts who made \$2 an hour (Oregonian, 1942, as cited in Pearson, 1996).

In addition to employment discrimination, housing segregation was also prevalent in Portland during the 1940s. Although public opinion and anti-African American sentiment restricted them from certain neighborhoods, there were native African American homeowners in a majority of the census tracks throughout the city (Pearson, 1996). Housing accommodations that native African Americans were accustomed to prior to the war quickly changed with the influx of African American migrant workers. With the influx of workers came the problem of housing the new workforce. According to Pearson (1996), White families would not house African American workers, forcing the native African American community to accommodate the growing African American population; however, their extremely limited resources were soon depleted (Pearson, 1996; Post, 1942, as cited in Pearson, 1996). Scared that workers would leave the area because of a lack of housing, the Kaiser corporation constructed Kaiserville (later renamed Vanport) for shipyard workers right outside Portland's city limits in August 1942. Eventually, Vanport became the largest World War II federal housing project in the United States, housing more than 42,000 residents by the end of 1943 and becoming the second largest population center in Oregon (Maben, 1987; Pearson, 1996).

Although under the guidelines of the Federal Housing Authority there was to be no segregation when it came to housing, the local housing authority in Portland actively placed African American workers in Vanport and another housing project named Guilds Lake. According to MacColl (1980), 
It [Vanport] was constructed so rapidly, however, that most of the housing units were constructed poorly and, because of wartime rationing, built with inferior materials. The apartments were small and cramped. According to one former resident, Vanport was never more than a huge collection of "crackerbox houses strung together fast and cheap." (as cited in Pearson, 1996, pp. 96-97)

Additionally, Vanport was situated in low-lying, reclaimed swamps that caused the land to be constantly muddy and attract insects and rodents; however crude and inhospitable, many families did not complain about the housing conditions because of the extreme difficulty in finding any housing (Pearson, 1996). Even when housing opened up within Portland's city limits, the local housing authority would encourage Whites to move in first (Pearson, 1996). By 1945, newspapers were mentioning the living conditions for African Americans residing in Portland:

In Portland the Negro people are passively witnessing the development of a first rate ghetto with all the potential for squalor, poverty, juvenile delinquency and crime.... It is obvious that the herding of Negroes into the district extending from Russell Street to the Steel Bridge and from Union Avenue to the river front portends economic and social problems of far reaching significance for this city. (The Observer, 1945, as cited in Pearson, 1996, p. 215)

Although these practices and observations are clearly discriminating, it was not something uncommon during the time period or a surprising response from an already racist White enclave in reaction to an influx in the African American population.

In 1948, prior to the flood, the local housing authority estimated that in the event of an emergency, it could find housing for no more than 1,500 people, and the Red Cross estimated it could find emergency housing for another 7,500 people; however, these numbers would leave more than half the population of Vanport with no place to live in the event of an emergency (Maben, 1987; Pearson, 1996). During May 1948, the river level rose, worrying residents into concerns about evacuations. Regardless of residents' concerns and the rising river water, the local housing authority posted bulletins on every door in Vanport stating that the project was safe and in no imminent danger; the very next day, 
May 31, 1948, at 4:17 p.m., the river water broke the dike, and within an hour the entire project of Vanport was submerged under 15 feet of water (Pearson, 1996).

At the time of the flood, many of the residents of Vanport were not at home; however, the number of people that drowned has always been disputed (Pearson, 1996). The city's coroner's office reported that only 15 people were killed in the flood (Maben, 1987; Pearson, 1996), but local residents tell stories of grave diggers working overtime to bury victims (Pearson, 1996; Portland's Albina Community, 1993). In an effort to acknowledge the loss of life, city officials proposed that only a limited number of bodies could be found because of them being carried down river into the Pacific Ocean, but many former Vanport residents felt that city officials were simply "withholding information" to avoid responsibility; some even believed that city officials wanted the Vanport project destroyed anyway (Journal, 1948a, 1948b, as cited in Pearson, 1996; Oregonian, 1994, as cited in Pearson, 1996; Time, 1948, as cited in Pearson, 1996). Additionally, Red Cross volunteers contributed to racial inequalities by telling African American refugees to "go back where [they] came from" as opposed to giving them aid (Nunn, 1994, as cited in Pearson, 1996, p. 215).

The refugees created by the flood had an extremely limited number of places to go. As had occurred prior to the construction of Vanport, local native African American residents who had homes outside the housing project attempted to aid some refugees, but they were not enough (Pearson, 1996). It is interesting that Vanport historians claim that African American refugees were welcomed into White homes, but most African American survivors do not have such memories. According to survivors, it was the African American community, with its already limited resources prior to the flood, that attempted to aid African American refugees (Pearson, 1996; Portland's Albina Community, 1993). In an attempt to deal with the refugees, city officials moved them to an abandoned shipyard barracks on Swan Island. Of the refugees placed on the island, African Americans outnumbered Whites by a ratio of nine to one, and many people were forced to shelter near the water's edge (The Observer, 1948, as cited in Pearson, 1996). Thomas Johnson, a survivor of the 
Mississippi Flood of 1927, feared that his children would fall into the river while playing around the edge of the island and proposed safety measures that were never implemented (Journal, 1948c, as cited in Pearson, 1996). In the aftermath of the flood, those African Americans that did remain in the area were again forced to live in segregated neighborhoods where families paid disproportionate shares of their incomes for shelter, contributing to "White flight" in surrounding neighborhoods (Bi-Monthly Report of the Urban League, 1952; Pearson, 1996; Urban League Report, circa 1948). Lessons were not learned from the Vanport experience. The politics of race and the resolve to never rebuild Vanport City dispersed families to other locations.

\section{HURRICANE KATRINA AND THE FLOODING OF NEW ORLEANS}

On August 29, 2005, the most devastating hurricane to hit the United States in generations made landfall in southern Louisiana. The amount of human suffering inflicted on the United States by Hurricane Katrina was greater than any other hurricane to strike the nation in several generations (Knabb, Rhome, \& Brown, 2005, p. 10). Although the initial estimation of 10,000 deaths was "overpessimistic" (Khudhairy et al., 2005, p. 6), as of September 16, the death toll reached 1,336, which included deaths that were both directly and indirectly related to Katrina in five ${ }^{5}$ Southern states (Knabb et al., 2005, p. 10). However disastrous the rest of the region may have been in the aftermath of the hurricane, the social injustices that took place in New Orleans gained international attention. On August 29, while the hurricane was hitting New Orleans, local residents and police had sought some sort of shelter, but tourists who could not leave were still in bars partying. Those residents who could escape Katrina were on their way north, and those that could not were scattered between hotels, hospitals, shelters, and the Superdome for shelter (Reagan et al., 2005, p. 19). Later that day, reporters were beginning to hear stories about bodies floating in the flood waters and police being incapable of reaching rescue boats to begin search and rescue attempts. There were reports of looting and of rising water trapping people in their 
homes, even forcing them into their attics and on top of their roofs (Reagan et al., 2005, p. 21). The city had become what one journalist had predicted early in May 2005:

Soon the geographical "bowl" of the Crescent City would fill up with the waters of the lake, leaving those unable to evacuate with little option but to cluster on rooftops-terrain they would have to share with hungry rats, fire ants, snakes, and perhaps alligators. The water itself would become a festering stew of sewage, gasoline, refinery chemicals and debris. (Mooney, 2005; see also Dyson, 2006, pp. 79-80)

Such imagery provided a clear picture of an environment not worth saving or even inhabitable by humans. Within a climate of media exaggerations and sensationalizing, fictional accounts of what happened became a part of the national discourse about what to do after Katrina. During this period, U.S. Representative Richard Baker (2005) stated,

We finally cleaned up public housing in New Orleans. We couldn't do it, but God did. (as cited in Reagan et al., 2005, p. 29)

Comments such as Baker's lie at the heart of the benign indifference, and oftentimes neglect, of the past that will shape public policies of the future and will affect the lives of disaster victims long after Katrina.

By August 30, water covered a majority of the city. After the rain stopped, sections of the city experienced looting. Some people viewed the looting as an act of survival and took what they needed while others took what they wanted. Many accounts of the bravery of individuals were recorded by the local media. These accounts recanted the stories of citizens endangering themselves to assist those infirmed or stranded and those who did not have provisions or could not obtain the necessary provisions until help arrived. Although both Whites and African Americans took part in the looting, the media portrayal of African Americans as criminals and Whites as survivors is another manifestation of the racial dichotomy. Such imagery reinforced the stereotype of "Black savagery"-a people beyond saving — which ultimately affected the relief efforts as 
law enforcements officers diverted much of their attention to those "looting" for food, water, and medications:

To be sure, besides taking food and items to survive-as did local officials and authorities, including aides to the mayor and the police, who were given the sort of pass that the masses would never receive-black folk took clothes and appliances and a few took guns. These blacks were drowned in a second flood of media and social criticism that vilified them for their inexcusable behavior. Even those critics who were sympathetic to the urgent conditions of the abandoned blacks felt pressured to embrace the frame of reference of black criminality before otherwise defending poor blacks. Such critics had to acknowledge that yes, these were awful and heinous acts, but still, distinctions must be made between acts of survival and acts of greed, wanton cynicism, or reckless morality. (Dyson, 2006, pp. 166-167)

Tierney, Bevc, and Kuligowski's (2006) research asks, "When such images are presented by government leaders, members of the white majority and the media-where people of color are presented as lawless elements, what extreme measures are they likely to advocate during future emergencies?" (p. 76; see also Fayer, 2006). Ultimately, it was not until the 4th day into the disaster that a decision was reached to begin evacuating 23,000 people from the overcrowded Superdome to the Astrodome in Houston, Texas (Reagan et al., 2005, p. 45).

On September 1, a new wave of problems manifested themselves when a Chinook helicopter transporting evacuees out of the Superdome was fired on, causing helicopter transports to be suspended temporarily (Reagan et al., 2005, p. 57). The suspension of air transport limited evacuation to buses only, allowing for 10,000 individuals to be evacuated, according to Mayor Nagin (Reagan et al., 2005, p. 82). Moreover, according to Mayor Nagin, by September 2, there were still approximately 50,000 survivors remaining on rooftops and an assortment of other places waiting to be rescued (Miller \& Rivera, in press; Reagan et al., 2005). Ironically, Fidel Castro offered to send 1,100 Cuban doctors and 26 tons of medicine to aid in the recovery of Katrina; however, his offer was not accepted (Reagan et al., 2005, p. 90). 
By September 4, 30,000 people were evacuated out of the Superdome and another 20,000 people were evacuated from the Convention Center (Reagan et al., 2005, p. 106). Because of the influx of so many African Americans into predominantly White areas, they were sometimes met with open resistance:

I don't how to get this point across without being blunt, but white supremacists have dropped the pretense of code-speak and are saying flat-out, "don't let them back in," using the n-word for emphasis. These raw words echoed at the police blockade on the Mississippi River bridge connecting New Orleans with the West Bank of suburban Jefferson Parish, where policemen from Gretna, a notoriously racist town, fired shots over the heads of Convention Center evacuees as they walked toward the on-ramp pursuant to instructions that buses were waiting on the other side to carry them to safety. (Powell, 2005; see also Dyson, 2006, p. 153)

The evacuation of the Superdome was initiated not only to displace people from the destruction left in the wake of Katrina but also to improve the safety of those individuals inside the Superdome. In the aftermath of the disaster, there were massive reports of murders, rapes, piles of dead bodies, and a number of other stories alluding to atrocious acts of behavior; however, weeks after the hurricane such reports were hard to substantiate (Thevenot \& Russell, 2005, p. A4). Again, racial biases had been manifested to create an imaginary scene of African Americans raping and murdering each other, incapable of controlling themselves in the face of confined habitation.

\section{CONTINUALLY NEGLECTED}

Zones of sacrifice. Although unique to the place and time, these natural disasters are significant in that they illustrate the clear divisions that exist when you have a large group of the population that

paradoxically assumes to be under the care of their own government, despite the fact that their displacement [lack of food, shelter, community education, and other resources] is often caused by the same state authorities [they turn to seek assistance] . . . thus relegating them to being [d]isconnected from the enjoyment of the rights normally associated with the dignity of being a citizen, their 
marginality become tantamount to statelessness. (Deng, 2006, pp. 218-219)

This adds up to what Bullard (1990a, 1990b, 2000) describes as the sacrificial zones, in that "the plantation system exploited not only humans but the land, the south has always been thought of as a sacrifice zone, a sort of dump for the rest of the nation's toxic waste" (as cited in Pastor et al., 2006, p. 3). In essence, history continues to repeat itself:

The Vanport Flood parallels the more recent Hurricane Katrina disaster in New Orleans. In both cases, public officials led the population to believe that the damage would be slight, and in both cases the government response to the disaster was harshly criticized. Racism toward the destruction of heavily-black areas was attributed to the poor response in both cases. (Wikipedia, 2006b)

All the cases represent zones of sacrifice, leaving the African American community in great disarray and fending for themselves, while suffering the brunt of catastrophe. As a result of public policy decisions, many people became internally displaced, some without the option of returning home.

Policy: Reactionary, ill-crafted public policy. As illustrated through discussion of the social situations faced by African Americans in the midst of natural disasters, the same situations that were faced in the beginning of the 20th century are continuing to manifest themselves in the beginning of the 21st. The behaviors of the state and federal government during the Mississippi and Vanport floods are perfect examples of government policy in the second historical stage of U.S. disaster policy. ${ }^{6}$ The governmental units responsible for disaster mitigation and relief took an exclusively reactionary approach to dealing with the disasters, increasing the likelihood of destruction during the flooding. During the Mississippi Flood, governmental bodies had only the Flood Control Act of 1917 (PL 64-367) in place to deal with the flood, which placed primary disaster response in the hands of local governments and the American Red Cross (Rivera \& Miller, 2006) as opposed to federal authorities. It was not until after the Mississippi 
Flood that the federal government took a more "active" role in local government mitigation:

Due to the wide-scale damage caused in the 1927 flood, President Coolidge signed a new Flood Control Act in 1928 (PL 70-391), which ended the use of "levees only" policy; moreover, the Flood Control Act of 1928 placed [responsibility] . . . in the hands of the federal government, which "even in the narrowest sense . . . set a precedent of direct, comprehensive, and vastly expanded federal involvement in local affairs." (Barry, 1997, p. 407)

Additionally, the Act of 1928 was in place during the Vanport flood. Although there was increased federal involvement, local officials were still mainly responsible for policy implementation, including where and to whom relief would be given.

Legislative reaction to the Vanport flood was slow, alluding that the federal government did not feel the situation significantly important; however, policy was passed in 1950 to alter existing relief programs. The Disaster Relief Act of 1950 (PL 81-875) allowed state governments to petition the federal government for assistance, but assistance was not necessarily automatic or guaranteed (Rivera \& Miller, 2006). Additionally, the federal government passed the Civil Defense Act of 1950, which, together with the Disaster Relief Act of 1950, allowed the federal government to contribute to the replacement and repair of local damaged infrastructure but not to private citizens (Comerio, 1998; Rivera \& Miller, 2006). The passage of these acts did little to aid African Americans in the aftermath of the Mississippi and Vanport floods because they left relief and federal funding placement in the hands of local governmental units that held racial sentiments. These changes continued to place African American communities at a disadvantage to White counterparts, thus perpetuating social vulnerability among the respective Black communities.

The legislation that was used to deal with Hurricane Katrina also left all mitigation efforts to the local governmental units for implementation and development (Rivera \& Miller, 2006). ${ }^{7}$ Furthermore, through Rivera and Miller's (2006) analysis of past mitigation and relief policy, the federal government's tendency to let local governments be responsible left the people of New Orleans and the Gulf 
Coast at the political benevolence of governmental authorities, which viewed socially vulnerable communities of the region not significant enough to warrant mitigation and relief plans. Federal reaction to Hurricane Katrina has pushed disaster relief policy into a third historical stage ${ }^{8}$ that places mitigation in the hands of the Department of Homeland Security. This change hopes to centralize relief and mitigation authority, making relief coordination more efficient (Bush, 2005). With the centralization of authority, the issue of social vulnerability among the African American community will be in direct correlation to federal policy; if African Americans or any other ethnic group are left vulnerable to disaster, not only are local governmental authorities responsible for their disadvantages, but the federal government also becomes responsible for allowing this vulnerability to take place.

\section{CONCLUSION: NATURAL DISASTERS AND CATALYSTS FOR CHANGE}

All of the disasters that have been discussed in this article have had the ability to teach both the local and federal governments about disaster policy deficiencies in addition to exposing the social situation of African Americans. In all three examples, the African American community has felt as though it was deliberately allowed to suffer in the aftermath of destruction because of neglect on the behalf of government units. This lack of civic trust on the behalf of the African American community has not been ungrounded in policy application throughout the history of disaster relief; however, as in the past, trust can be fostered among the African American community but only through active measures:

Breaking the hardened cycle of poverty and despair is a major challenge in the postdisaster recovery effort. The real work of healing after Katrina and Rita [in addition to all other disasters] must be done by residents, public officials, and businesspeople who must plan for the rebirth of their communities. To a large degree, the future confidence and trust in government will depend on local people with the help of supportive national and state governments. (Berke \& Campanella, 2006, p. 201) 
Additionally, participation by local residents, especially socially disadvantaged groups, can improve the consistency of policy solutions and aid in avoiding potential variances in plan implementation among different segments of the population (see Berke \& Campanella, 2006; Miller \& Rivera, 2006). As depicted in the examples of the Mississippi Flood of 1927, the Vanport Flood of $1948,{ }^{9}$ and Hurricane Katrina, the social situation faced by African Americans, and now other ethnic groups, has changed little. Again, Hurricane Katrina brings the nation to a time when social vulnerability and disadvantage can be improved, especially in reference to natural disasters. Natural disasters have had a profound and direct influence on the migration patterns of African Americans because of their inability to be given sufficient attention in the advent of emergency situations. Although this directly affects the viability of the African American communities within disaster affected regions, it has a significant effect on the social structure of locations where they immigrate to, creating social imbalances that have created racial animosity expressed through policy implementation, or lack thereof in the past.

\section{NOTES}

1. For the sake of this discussion, we conceptualize disaster as a naturally occurring event in which society, or a unit of society, incurs damages, resulting in the disruption of routine functioning because of an inability of the social network to maintain safe conditions in the physical surroundings (see Miller, 1997, p. 11).

2. When the Emancipation Proclamation was signed, less than $8 \%$ of the African American population lived in the Northeast or Midwest. Even by 1900, approximately 90\% of all African Americans still resided in the South. However, migration from the South has long been a significant feature of African American history. An early exodus from the South occurred between 1879 and 1881, when about 60,000 African Americans moved into Kansas and others settled in the Oklahoma Indian Territories in search of social and economic freedom (Library of Congress, 2005).

3. For more information, see Oliver-Smith (2005). Also see Wikipedia (2006a) and WGBH Educational Foundation (2001). More than 13,000 evacuees near Greenville, Mississippi, were gathered from area farms and evacuated to the crest of an unbroken levee. They were stranded there for days without food or clean water, while boats arrived to evacuate White women and children. Many African Americans were detained and forced to labor at gunpoint during the flood relief efforts.

4. Executive Order 8802.

5. By September 16, 2005, the death toll had reached 1,090 in Louisiana, 228 in Mississippi, 14 in Florida, 2 in Georgia, and 2 in Alabama (Knabb et al., 2005, p. 10). 
6. In Stage Two of U.S. disaster policy development, attention is given to social issues associated with natural disasters such as rebuilding the local economic infrastructure and private property; however, implementation and mitigation responsibility is primarily the responsibility of the local governments (Rivera \& Miller, 2006).

7. The most influential legislation in place to deal with Hurricane Katrina was the Disaster Mitigation Act of 2000 (PL 106-390) that placed all spending and mitigation practices in the hands of the state and local governments.

8. Stage Three of U.S. natural disaster policy development is deemed "Natural Disaster as National Security-Militarization Approach" by Rivera and Miller (2006). This stage is different from all preceding historical stages because of the level of federal involvement in local and state mitigation programs and the placement of disaster preparedness in the same category as counterterrorism.

9. Some leaders argue the merits of the migration of residents from Vanport as a step forward for race relations. Such advancements and the ultimate dismantling of segregated housing policies occurred in Portland:

Vanport's destruction facilitated the integration of a large African American population into North and Northeast Portland. Indeed, some black leaders argued that the flood was ultimately beneficial for the city's black community. Vanport, argued National Urban League director Lester Granger, was a "nasty, segregated ghetto" where "[N]egroes lived in the same patterns as they did in the South." The flood that wiped out the district, he continued, was a benefit in that it allowed blacks to further integrate into Portland's society. (Wikipedia, 2006b)

\section{REFERENCES}

1940 census report (MSS 1585). (1940). Portland: Stella Maris House Papers, Oregon Historical Society.

Baker, R. (2005). Points of View August 29, 2005. In M. Reagan, G. Webb, C. Harkleroad, C., L. Reagan, \& D. Murphy (Eds.), Katrina state of emergency (pp. 18-29). Kansas City, MO: Lionheart Books.

Barry, J. M. (1997). Rising tide: The Great Mississippi Flood of 1927 and how it changed America. New York: Simon \& Schuster.

Berke, P. R., \& Campanella, T. J. (2006). Planning for postdisaster resiliency. ANNALS American Academy of Political and Social Science, 604, 192-207.

Bi-monthly report of the Urban League (Box 3. MSS 1585). (1952). Portland: Stella Maris House Papers, Oregon Historical Society.

Bullard, R. D. (1990a). Dumping in Dixie: Race, class and environmental quality. Boulder, CO: Westview.

Bullard, R. D. (1990b). Ecological inequalities and the new South: Black communities under siege. Journal of Ethnic Studies, 17(Winter), 101-115.

Bullard, R. D. (2000). Dumping in Dixie: Race, class and environmental quality (3rd ed.). Boulder, CO: Westview.

Bush, G. (2005). September 15, 2005 President discusses hurricane relief in address to the nation (Jackson Square, New Orleans, Louisiana). Retrieved November 26, 2005, from http://www.whitehouse.gov/news/releases/2005/09/20050915-8.html

Carson, R. (1962). Silent spring. Boston: Houghton Mifflin Company. 
Comerio, M. (1998). Disaster hits home: New policy for urban housing recovery. Berkeley: University of California Press.

Davis, R. (2003). The history of Jim Crow: Escaping Jim Crow. Retrieved June 26, 2006, from http://www.jimcrowhistory.org/history/escaping.htm

Deng, F. M. (2006). Divided nations: The paradox of national protection. ANNALS American Academy of Political and Social Science, 603, 217-225.

Dyson, M. E. (2006). Come hell of high water: Hurricane Katrina and the color of disaster. New York: Basic Civitas Books.

Fayer, H. (2006). Shelter from the storm: Repairing the National Emergency Management System after Hurricane Katrina. ANNALS American Academy of Political and Social Science, 604, 288-291.

Khudhairy, D. A, Annunziato, A., Best, C., Bettio, M., Caravaggi, I., Confalonieri, R., et al. (2005). Katrina event information report. European Commission Joint Research Centre. Retrieved January 2, 2006, from http://europa.eu.int/comm/external_relations/us/ hurricanekatrina/jrc_reports/jrc_report01_14_09_05.pdf

Knabb, R. D, Rhome, J. R., \& Brown, D. P. (2005). Tropical cyclone report Hurricane Katrina 23-30 August 2005 (National Hurricane Center). Retrieved January 2, 2006, from http://www.nhc.noaa.gov/pdf/TCR-AL122005_Katrina.pdf

Library of Congress. (2005). The African American mosaic: A Library of Congress resource guide for the study of Black history \& culture. Retrieved June 26, 2006, from http://afroamhistory.about.com/gi/dynamic/offsite.htm?zi=1/XJ\&sdn=afroamhistory\&zu=http\%3A\%2F\%2Flcweb.loc.gov\%2Fexhibits\%2Fafrican\%2Fafam008.html

Maben, M. (1987). Vanport. Portland: Oregon Historical Society Press.

MacColl, E. K. (1980). The growth of a city: Power and politics in Portland, Oregon 1915-1950. Portland: Oregon Historical Society Press.

Miller, D. S. (1997). The construction of competing disaster narratives: Media coverage of the distribution of risk following a technological disaster. Unpublished doctoral dissertation, Mississippi State University.

Miller, D. S., \& Rivera, J. D. (2006). Guiding principles: Rebuilding trust in government and public policy in the aftermath of Hurricane Katrina. Journal of Public Management \& Social Policy, 12(1), 37-48.

Miller, D. S., \& Rivera, J. D. (in press). Setting the stage: Roots of social inequity and the human tragedy of Hurricane Katrina. In R. S. Swan \& K. A. Bates (Eds.), Through the eye of Katrina: Social justice in the United States. Durham, NC: Carolina Academic Press.

Mooney, C. (2005, May 23). Thinking big about hurricanes: It's time to get serious about saving New Orleans. The American Protest. Retrieved June 25, 2006, from http://www .prospect.org/web/page. $w$ w?section=root\&name $=$ ViewWeb\&articleId $=9754$

National Flood Commission. (1927). See undated report from late January 1927 to February 1927.

Oliver-Smith, A. (2005). Disasters and forced migration in the $21^{\text {st }}$ century. Retrieved June 20, 2006, from http://understandingkatrina.ssrc.org/Oliver-Smith/pf/

Pastor, M., Bullard, R. D., Boyce, J. K., Fothergill, A., Morello-Frosch, R., \& Wright, B. (2006). In the wake of the storm: Environment, disaster, and race after Katrina. New York: Russell Sage Foundation.

Pearson, R. N. (1996). African Americans in Portland, Oregon, 1940-1950: Work and living conditions - a social history. Unpublished dissertation, Washington State University Department of History, Pullman.

Portland's albina community: The history of Portland's African American community (1850 to the present). (1993). Pamphlet found at Portland Bureau of Planning. 
Powell, L. N. (2005). New Orleans: An American Pompeii? Unpublished manuscript.

Public Broadcasting System (PBS). (2000). American experience: Timeline. Retrieved September 29, 2006, from http://www.pbs.org/wgbh/amex/flood/timeline/timeline2.html Reagan, M., Webb, G., Harkleroad, C., Brown, C., Reagan, L., \& Murphy, D. (2005). Katrina state of emergency. Kansas City, MO: Lionheart Books.

Rivera, J. D., \& Miller, D. S. (2006). A brief history of the evolution of United States' natural disaster policy. Journal of Public Management \& Social Policy, 12(1), 5-14.

Slivka, J. (2005, September 12). Another flood that stunned America. US News and World Report, p. 26.

Thevenot, B., \& Russell, G. (2005, September 26). Rape. murder. gunfights. The TimesPicayune, pp. A1, A4-A5.

Tierney, K., Bevc, C., \& Kuligowski, E. (2006). Metaphors matter: Disaster myths, media frames, and their consequences in Hurricane Katrina. ANNALS American Academy of Political and Social Science, 604, 57-81.

Urban League report - The battle against bigotry (Box 3). (circa 1948). Portland: Stella Maris House Papers, Oregon Historical Society.

WGBH Educational Foundation. (2001). Fatal flood. New York: Public Broadcasting Service.

Wikipedia. (2006a). Great Mississippi Flood of 1927. Retrieved June 29, 2006, from http://www.enwikipedia.org/wiki/Great_Mississippi_Flood_of_1927

Wikipedia. (2006b). Vanport, Oregon. Retrieved June 28, 2006, from http://www.en.wikipedia .org/wiki/Vanport,_Oregon

Jason David Rivera is a research associate at Rowan University in the Liberal Arts and Sciences Institute for Research and Community Service. He has recently worked on research dealing with public policy in reference to disaster mitigation and relief, social justice in the face of disasters, the reconfiguration of landscapes and their affect on local and global politics, as well as research pertaining to improving university and community relations. Examples of his research can be found in Journal of Public Management and Social Policy, Space and Culture: An International Journal of Social Spaces, Journal for the Study of Radicalism, and International Journal of the Humanities.

DeMond Shondell Miller, PhD, is an associate professor of sociology and director of the Liberal Arts and Sciences Institute for Research and Community Service at Rowan University (Glassboro, New Jersey). He has worked as an evaluator for alcohol and tobacco social norms projects and as a principal investigator to facilitate research projects involving environmental issues and community satisfaction. His primary area of specialization is environmental sociology, disaster studies, the study of the social construction of place, community development, and social impact assessment. He has presented and published several professional papers; recent examples of such work can be found in The Researcher, The Qualitative Report, Journal of Emotional Abuse, Space and Culture: An International Journal of Social Spaces, International Journal of the Humanities, Journal for the Study of Radicalism, Journal of Public Management and Social Policy, and The Southeastern Sociological Review. 